\title{
Sorte skyer over Georgien
}

Mikael Hertoft

\section{Oppositionen nægter at anerkende resultatet af parlamentsvalget og vil boycotte parlamentet. OSCE er heller ikke begejstret}

Da Mikheil Saakashvili, Georgiens præsident, besøgte Danmark i sidste efterår, var alt tilsyneladende fryd $o g$ gammen i Georgien.

Præsidenten talte i Det Udenrigspolitiske selskab, hvor han sagde, at Georgien var en succeshistorie og understregede Georgiens fremskridt på områder som fx politireform, vejbyggeri og kampen mod korruption.

Han understregede, at selv om nogle af hans reformer havde været upopulære, så var hans regering stadig populær i befolkningen. På Vibeke Sperlings spørgsmål om ikke beslutningerne i Georgien blev taget af en meget snæver kreds omkring præsidenten, svarede han at roserevolutionens team stadig var intakt.

Men kort tid efter præsidentens besøg i Danmark brød der uroligheder ud i Georgien, og situationen er yderst spændt i forhold til Abkhasien og Sydossetien, udbryderområder fra Georgien, og til Rusland mod nord.

\section{Efterårets krise}

Den politiske krise i Georgien startede i oktober 2007, da den fyrede forsvarsminister Irakli Okruashvili beskyldte Saakashvili og kredsen omkring ham for korruption. Dette var en af de udløsende årsager til massedemonstrationer, der krævede regeringens afgang. Disse demonstrationer var ikke større eller mere frygtindgydende, end hvad man har set i mange europæiske lande - men måske er situationen i Georgien grundlæggende mere ustabil og regeringen svagere funderet. Derfor udgør selv middelstore demonstrationer som dem i efteråret en trussel.

I hvert fald reagerede præsidenten med en massiv politimæssig nedkæmpning af demonstrationerne den 7. november med anvendelse af tæv og tåregas i en målestok, der chokerede befolkningen i Georgien, selv om voldsanvendelsen ikke hæver sig over, hvad man har set flere gange i fx Danmark. 


\section{MIKAEL HERTOFT}

I Georgien udløste dette imidlertid voldsomme protester. Også fra udlandet kom der kritik af den indførte undtagelsestilstand, da politiet stormede, ødelagde og lukkede den største oppositionelle TV-kanal.

Georgien blev kastet ud i en krise både mellem præsidenten og folket og mellem præsidenten og oppositionen, samtidig med at Saakashvili brat tabte international troværdighed.

\section{Præsident- og parlamentsvalg}

Præsidenten udskrev et tidligt præsidentvalg 5. januar 2008, hvor han blev genvalgt med bare 53 procent af stemmerne - og hvor valgets afholdelse langt fra var uproblematisk. Samtidig var der en folkeafstemning, om der skulle være parlamentsvalg, og dette blev vedtaget.

I løbet af foråret skulle der så være forhandlinger om valglov og den tekniske sammensætning af det nye parlament. Saakashvili havde lovet oppositionen at søge konsensus om disse vigtige forfatningsændringer - men i stedet valgte han med regeringspartiets bekvemme majoritet i det gamle parlament at gennemtrumfe sin løsning, uden at oppositionen fik nogen indflydelse.

Efter den nye valglov blev der væsentligt færre medlemmer i parlamentet, og af dem skal halvdelen vælges på partilister og den anden halvdel ved flertalsvalg i enkeltmandskredse. OSCE kritiserede, at enkeltmandskredsene var af så forskellig størrelse fra omkring 6.000 til omkring 140.000 vælgere pr. kreds, og at vægten af hver stemme derfor var højest ujævn. Den nye model favoriserer i høj grad regeringspartiet, som det også blev dokumenteret $\mathrm{i}$ valgresultatet. Oppositionen blev rasende, naturligvis, men valget blev udskrevet til 21. maj og afholdt med massiv deltagelse af internationale observatører.

Op til valget kom der endnu en afskalning fra de regerende cirkler, idet parlamentets formand og en af lederne af roserevolutionen, Nino Burjanadze, erklærede, at hun ikke ville genopstille til parlamentet. Hun må have været meget vred, da hun tog dette skridt, for hun gjorde det på den måde, der var mest egnet til at genere regeringspartiet. Hun indgav sin erklæring en halv time før deadline for indlevering af lister over opstillede til den centrale valgkommission.

Resultatet blev et tragikomisk mellemspil, hvor regeringspartiet hævdede, at de havde afleveret en liste, og valgkommissionen at de havde modtaget en sådan liste - men hvor ingen, hverken opposition eller valgobservatører, kunne få listen at se før adskillige timer senere.

Valgkampen var domineret af regeringspartiet - Den Forenede Nationale Bevægelse - der både havde flere penge end nogen andre og også i høj grad brugte administrative ressourcer - dvs. statsapparatet - i 
sin valgkamp. Selv om oppositionen ofte hævdede, at dens medlemmer blev lagt under pres, og man havde problemer, så førte flere oppositionspartier en nogenlunde energisk valgkamp.

Generelt vurderede internationale observatører, at valget var 'på linje med international standard', men at der var 'et antal problemer', der gjorde, at implementeringen af internationale standarder var 'ujæun og ukomplet'. Der er derfor ifølge OSCE 'en mangel på tillid' til valgprocessen, som er en udfordring, der skal overvindes. Oppositionen, der havde mange observatører, og en del andre NGO-observatører var endnu mere kritiske.

Klager fra NGO'er og fra visse internationale observatører førte til dusinvis af annullerede valgsteder. Den mangel på tillid til valgresultatet, som OSCE omtalte, er meget udbredt blandt georgiere, som udtrykker stor skepsis over for de metoder, der er blevet anvendt for, at
Den Forenede Nationale Bevægelse har vundet valget.

\section{Valgresultatet}

Resultatet af valget 21. maj blev, at regeringspartiet med under 59 procent af stemmerne fik 79 procent af mandaterne. En sådan dominans betyder, at regeringspartiet, hvis det ønsker det, også kan ændre forfatningen, idet dette kun kræver to tredjedeles flertal. Oppositionen har vedtaget at boykotte parlamentet, selv om nogle medlemmer siger, de vil indtage deres pladser.

Oppositionen er meget fragmenteret. Den største strømning er Den Forenede Opposition - Nyt højre, bestående af ni partier (nu otte - et har forladt koalitionen efter valget). Blokken adskiller sig politisk ikke meget fra Saakashvili, og mange af dens ledere har også tidligere været en del af Saakashvilis team. Men netop denne strømning var mest kritisk i forhold til præsidenten.

\begin{tabular}{|l|r|r|}
\hline \multicolumn{2}{|c|}{ Resultat af Georgiens valg til parlamentsvalget 21. maj 2008 } \\
\hline Antal vælgere: 3.465.736. Antal deltagere i valget: 1.840.407 \\
\hline Parti eller politisk blok & Stemmer \% & Mandater \\
\hline Den Forenede Nationale Bevægelse (Præsident Saakashvili) & $59,18 \%$ & 119 \\
\hline Den Forenede Opposition, Nyt højre (9 partier) & $17.73 \%$ & 17 \\
\hline De Kristelige Demokrater (konservative, ortodokse) & $8,66 \%$ & 6 \\
\hline Arbejderpartiet & $7,44 \%$ & $2 *$ \\
\hline Republikanerne & - & 6 \\
\hline \multicolumn{2}{|c|}{ Republikanerne kom under spcerregrcensen på 5\%, men fik valgt 2 i enkeltmandskredse. } \\
\hline
\end{tabular}




\section{MIKAEL HERTOFT}

De Kristelige Demokrater er et helt nyt parti, som er stærkt konservativt og ortodokst, og som knap nok kan regnes med til oppositionen ( og bl.a. ikke vil boykotte parlamentet). Arbejderpartiet er en slags venstrefløj, men ikke særlig markant.

En række andre partier kom ikke over fem procents spærregrænsen. Det gælder bl.a. republikanerne der mere er en slags klassisk dissidentstrømning, og som fik valgt to medlemmer af parlamentet i enkeltmandskredse.

Man kan konstatere, at i dagens Georgien er der ikke noget alternativ til Saakashvili, men der er en meget stærk mistillid til ham og til de processer, der har ledt til hans og hans parlamentsflertals valg.

\section{Særtræk ved det politiske spil}

Som i de øvrige lande i det tidligere Sovjetunionen er der ingen stærk partitradition eller -struktur i Georgien. Sovjetunionen var et etpartisystem, hvor partierne var ophævet på nær et, og kommunistpartiet selv var egentlig ikke noget parti, men en del af statsapparatet. Da Sovjetunionen brød sammen, og kommunistpartiet mistede magten, efterlod det sig et vakuum.

I Georgien er der i modsætning til Rusland i dag slet intet kommunistparti tilbage. Magten gled så over $\mathrm{i}$ strukturer, der er individuelle og klanbaserede.
Ordet klan skal her ikke forstås som noget mystisk. I et samfund hvor staten er svag eller udefra påtvunget, vil mennesker overleve ved at etablere sociale netværk - strukturer for gensidig hjælp. I et hierarkisk samfund, som det georgiske, vil der naturligt være ledere af sådanne strukturer - og det er sådanne personligheder, snarere end ideologi, der konstituerer politiske partier.

Oppositionen består således i høj grad af politikere, der er gået over fra regeringen og regeringspartiet, og hvor det er svært at se en egentlig politisk forskel, men derimod let at få fortalt hvilke personlige magtkampe, der har ført til overgang fra regeringsparti til opposition.

I hele det postsovjetiske område har man nu en struktur, hvor det er præsidenten, der udpeger de centrale ledere i de lokale administrationer, der så igen udnævner deres repræsentanter. Den udøvende del af det civile statsapparat er således direkte præsidentstyret. Når præsidenten skifter, skifter embedsmændene også langt ned i systemet.

De råd, der som regel også eksisterer som lokalt valgte repræsentanter for folket, har mindre administrative ressourcer og beslutningskompetence samt så godt som ingen direkte magt. Dette gælder i Ukraine, Rusland og også i Georgien.

Denne måde at organisere staten på kan føres tilbage til strukturerne i sovjetsystemet, men også videre tilbage til, hvordan tingene var organi- 
seret under zaren, og bredere til en feudal samfundsstruktur, som har overlevet alle omvæltninger, fordi den passer enhver ny magthaver. Man kan sige, at det herskende parti i meget høj grad smelter sammen med statsapparatet.

Dette gælder også i dag fordi Saakashvili, som han fremhævede i København, startede sin tid som præsident med en grundlæggende politireform. Derved fik han gjort op med en masse politikorruption den mest åbenlyse slags, hvor vejpatruljer krævede penge af folk for at lade dem køre videre - men hvad der er mindre omtalt er, at han også fik etableret et politi, der er meget loyalt over for netop Saakashvili.

Det er derfor ikke overraskende, at statsapparatet også er aktivt i valgkampen, som det i høj grad var tilfældet i Georgien.

\section{Forholdet til Rusland}

Rusland har gennemført noget, der minder om boykot af alt georgisk. For et par år siden stoppede Den Russiske Føderation for import af georgisk vin og mineralvand (den berømte Borjomi, en af verdens bedste mineralvand), lukkede for visa til georgiske statsborgere og stoppede endda flyvningerne mellem Tbilisi og Moskva (flyvningerne er siden blevet genoptaget).

Disse skridt fra russisk side er temmelig uforståelige. For boykotten har nok ramt Georgien bredt, men rammer i særlig grad ramt de elementer i det russiske og georgiske samfund, der kunne sikre kulturelle og økonomiske bånd mellem Georgien og Rusland: Den økonomiske boykot rammer de handelsmænd og sektorer, der før hovedsagelig arbejdede på det russiske marked. Visumstoppet rammer især det armenske mindretal, der i høj grad levede af at rejse til Rusland og arbejde i sommerhalvåret.

Og bølgen af fjendtlighed mod georgiere, som bl.a. medførte politirazziaer i det georgiske hus på Arbat i hjertet af Moskva, rammer især de georgiere, der bor millioner af i Rusland. Resultatet af den russiske politik har derfor været, at Ruslands fjender i Kaukasus har fået vind i sejlene, mens Ruslands venner har mistet argumenterne for et tæt forhold til Rusland.

Ikke desto mindre er Georgien stadig med i SNG. En praktisk grund er måske, at det formelt er SNG, der står for de fredsbevarende styrker i Abkhasien, og selv om de er russisk dominerede, så giver det $\mathrm{i}$ hvert fald formelt Georgien ret til at få indsigt i operationerne.

En bredere forklaring er måske, at det ikke er så nemt for Georgien at melde sig ud af sin postsovjetiske virkelighed. Naboerne (bortset fra Tyrkiet) har trods alt alle en fortid i Sovjetunionen.

Et af Ruslands største prestigeprojekter er planerne for vinterolympiaden i Sotji i 2014, umiddelbart nord 
for Abkhasien. Dette projekt vil bringe storpolitik og international opmærksomhed til området. Når de ser på, hvordan olympiaden i Beijing er blevet brugt til at rette søgelyset mod Tibet og spørgsmålet om menneskerettigheder i Kina, så må russiske magthavere frygte at noget tilsvarende kan ske med vinterolympiaden. Dette giver Rusland en stærk interesse i at få normaliseret forholdet til Georgien.

Samtidig vil vinterolympiaden også sætte skub i Ruslands planer for integration af Abkhasien i Ruslands økonomi, idet man planlægger at anlægge cementfabrikker i Abkhasien til byggeriet op til olympiaden. Endnu er der længe til 2014, og man kan forestille sig at Rusland i de næste 3-4 år vil øge presset på Georgien for at få løst konflikterne i Abkhasien og Sydossetien, men på russiske betingelser.

Ruslands interesse er dels at få sat et endelig punktum for Georgiens ambitioner om NATO-medlemskab og at modvirke en reintegration af Sydossetien og Abkhasien i Georgien. Hvis det ikke lykkes Rusland at få sin vilje i løbet af 3-4 år, så vil Rusland derimod være tvunget til at søge en form for diplomatisk udglatning i forhold til Georgien for at undgå skandaler omkring vinterolympiaden.

\section{Georgien som USA's allierede}

USA har i flere år behandlet Georgi- en som en tæt allieret, udsigt til NATO-medlemskab eller ej. Georgien er et betydningsfuldt medlem af en anden alliance: 'Koalitionen af Villige', de få lande der opretholder et militært engagement og medansvar for USA's besættelse af Irak.

Mens lande som Ukraine og Danmark har trukket sig ud, og England og Australien har skåret voldsomt ned på deres tropper (Australien har netop trukket 500 mand ud og har nu kun 300 soldater i Irak, hvoraf 110 bevogter den australske ambassade), så vokser Georgiens engagement i Irak til stadighed - Georgiens militære engagement i Irak er nu det tredjestørste efter USA selv og Storbritannien. Georgien ligger ikke langt fra Irak.

Georgien får så til gengæld en omfattende, amerikansk finansieret fornyelse af sin hær efter NATOstandard. Dette opfattes naturligvis som en trussel fra russisk og ikke mindst fra abkhasisk og sydossetisk side. (Man må ikke glemme, at konflikten med de to udbryderområder ikke kun er en konflikt med Rusland, men også med nationale minoriteter, der energisk modsætter sig at blive underordnet Tbilisi, som de mangler tillid til). Rusland føler sig sikkerhedsmæssigt truet af NATOs udvidelse mod øst og bliver helt hysterisk ved tanken om georgisk NATO-medlemskab.

Den nuværende amerikanske tilstedeværelse er en torn i den russiske bjørns fod. 


\section{Krænkelser på begge sider}

Den 22. april - dvs. midt under valgkampen til parlamentsvalget - blev et ubemandet fly - en såkaldt drone eller på engelsk Unmanned Areal Vehicle - UAV, skudt ned over den abkhasiske kyst. Flyet var et Hermes 450 - et rekognosceringsfly, der kan flyve i op mod 20 timer med en effektiv rækkevidde på 500-600 km fra basen, og som kan armeres med to hellfire missiler. De små ubemandede fly bruges af det israelske militær som angrebsfly.

I dansk presse, og i endnu højere grad i georgisk presse, er det blevet skildret som russisk aggression, at et sådant fly er blevet skudt ned. FN kom godt en måned efter nedskydningen med en rapport. Rapporten bekræfter ud fra det materiale, der er stillet til rådighed fra georgisk side, at der med stor sandsynlighed er tale om nedskydning fra et russisk fly.

Dette er en krænkelse af våbenhvileaftalen indgået i Moskva i 1994, slår FN's rapport fast.

Men hvad der er meget underrapporteret i international presse er, at Georgien bliver udsat for præcis lige så skarp en kritik fra FN. Det er en krænkelse af våbenhvileaftalen, at Georgien overflyver Abkhasien med ubemandede spionfly. "Det siger sig selv, at den form for militær efterretningsindsamling på abkhasisk territorium må blive set som forløber for en militær operation, specielt i en periode med et spændt forhold mellem parterne."

FN's rapport tilføjer, at det er værd at bemærke, at den abkhasiske side har rapporteret 16 overflyvninger med ubemandende fly siden august 2007.

Rapporten, som altså kritiserer både Georgien og Rusland for krænkelse af våbenhvileaftalen, slutter med en påmindelse til parterne om at "En våbenhviletilstand har en stor fordel - at den forhindrer krig. På den anden side pålægger den også en begrænsning i friheden hos parterne, inklusive den at tage skridt, som kan og vil blive opfattet som trusler fra den anden side."

På selve valgdagen blev to busser, der havde transporteret vælgere, beskudt med granater og ødelagt i Kurcha tæt på den abkhasiske grænse. Episoden fik massiv dækning i georgisk TV i valgudsendelserne, og georgisk TV hævede, at busserne var blevet beskudt af abkhasiske separatister.

Den norske Helsinki Komite havde Ivar Dale og Aage Borchgrevink som observatører i området, og de talte med en række lokale øjnevidner, der alle mente, at episoden var iscenesat af den georgiske side som mediebegivenhed omkring valget.

Hvad der er sandheden er svært at sige, og sådan er det som oftest i Kaukasus - der er påstande og modpåstande og at komme ind til kernen og finde ud af, hvad der sandt, er vanskeligt. 


\section{MIKAEL HERTOFT}

\section{Fred og stabilitet}

Georgien er nu et vigtigt transitland for olie og snart gas fra Aserbajdsjan og Centralasiens oliefelter. Georgien er ved at åbne nye vej- og togforbindelser til Tyrkiet, og dermed vil Georgien også blive transitland mellem Aserbajdsjan og Armenien og Tyrkiet. Det vil sikre den georgiske stat relativt små, men stabile indtægter.

Den georgiske stat er ikke særlig stabil, men det er ikke noget nyt. Georgiens stabilitet ligger i noget andet - i folket, dets sammenhold og dets tilhørsforhold til den georgi- ske nation. Selv på et kort ophold i Georgien kan man ikke undgå at blive inviteret til en georgisk fest en supra. Mad og drikke er vigtig ved en sådan fest - men det vigtigste er, at der er en Tamada - en slags leder af festen, der er den ældste og øverste i hierarkiet blandt værterne. Tamadaen udbringer skåltaler, og et par af dem vil uvægerligt være for Georgien og for fred!

Mikael Hertoft er cand. mag $i$ russisk og øststatskundskab og har netop varet langtidsobservatør ved parlamentsvalget $i$ Georgien. 